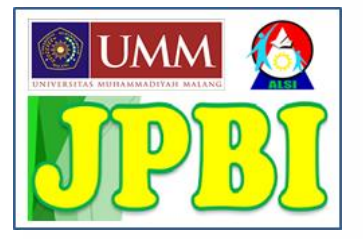

\title{
Improving student learning outcomes in science subjects through the implementation of PBL-based module
}

Eva Nursa'ban a,1,*, Mohammad Masykuri a,2, Sri Yamtinah a,3

a Master of Science Education, Postgraduate School, Universitas Negeri Sebelas Maret. Jl. Ir. Sutami No. 36A, Surakarta,

Central Java, 57126, Indonesia

${ }^{1}$ evanursaban@gmail.com*; ${ }^{2}$ mmasykuri@staff.uns.ac.id, ${ }^{3}$ jengtina_sp@yahoo.com

${ }^{*}$ Corresponding author

\begin{tabular}{|c|c|}
\hline ARTICLE INFO & ABSTRACT \\
\hline $\begin{array}{l}\text { Article history } \\
\text { Received January 25, } 2019 \\
\text { Revised June 17, 2019 } \\
\text { Accepted June 26, } 2019 \\
\text { Published June 30, } 2019 \\
\text { Keywords } \\
\text { PBL-based module } \\
\text { Problem-based learning } \\
\text { Science learning outcomes }\end{array}$ & $\begin{array}{l}\text { PBL is a one of the learning model which has been reported can improve } \\
\text { student learning outcomes optimally. Unfortunately, the frequency of } \\
\text { implementing PBL and the teacher knowledge level about PBL is not optimal } \\
\text { yet. This quantitative descriptive study aimed at determining the effect of PBL- } \\
\text { based modules implementation on student learning outcomes. The population } \\
\text { of this study was the XI grade students of SMAN } 2 \text { Wera in which the sample } \\
\text { was the students of XI-Natural Science Class. Test was chosen as an } \\
\text { instrument in the data collection process which was given at the beginning and } \\
\text { the end of the implementation. The dependent-test was performed, after } \\
\text { collecting the data. The study results indicated that the student learning } \\
\text { outcomes increased significantly. Therefore, the application of PBL-based } \\
\text { module is recommended to be carried out during science learning of XI } \\
\text { graders. }\end{array}$ \\
\hline
\end{tabular}

Copyright @ 2019, Nursa'ban, et al This is an open access article under the CC-BY-SA license

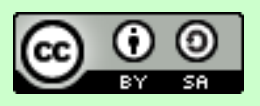

How to cite: Nursa'ban, E., Masykuri, M., \& Yamtinah, S (2019). Improving student learning outcomes in science subjects through the implementation of PBL-based module. JPBI (Jurnal Pendidikan Biologi Indonesia), 5(2), 269-276. doi: https://doi.org/10.22219/jpbi.v5i2.7534

\section{INTRODUCTION}

Teaching science to students is a challenging and complicated process (Fleischner et al., 2017; Kadbey, Dickson, \& McMinn, 2015; Omorogbe \& Ewansiha, 2013). The reason is that science is considered a cluster of difficult (Buah \& Akuffo, 2017; Etobro \& Fabinu, 2017) and boring subjects (Shirazi, 2017). Besides, teachers must be aware that science learning often involves the fundamental knowledge that has been brought by students (Arends, 2012). This fundamental knowledge can sometimes help students understand science, sometimes also causing science misconceptions (Barke, Hazari, \& Yitbarek, 2009; Fleischner et al., 2017; Karpudewan, Zain, \& Chandrasegaran, 2017). Furthermore, science learning is also required to associate content with the daily lives of students (Asrizal, Amran, Ananda, \& Festiyed, 2017; Suryawati \& Osman, 2018). 
Apart from the various challenges that have been mentioned, mastery of science by students is a significant factor in future national development (Fleischner et al., 2017; Kola, 2013).

Implementation of cooperative learning based on constructivism is a recommended step taken by science teachers (Ajaja, 2013; Ajaja \& Eravwoke, 2010; Arends, 2012; Dogra, 2010; Rahayu, 2017; Slavin, 2014). Cooperative learning will help teachers optimize limited learning time. In addition, cooperative learning can overcome students' boredom because it can maintain their learning motivation (Alfares, 2017; Lai, 2011). On the other hand, the principle of constructivism will facilitate the teacher to associate science concepts that will be studied by students with the scientific concepts that students have brought before entering class (Shaaruddin \& Mohamad, 2017). The application of constructivism learning can also minimize misconceptions in science learning (Putrayasa, 2018; Tompo, Ahmad, \& Muris, 2016). One of cooperative learning with constructivism approach is problem-based Learning (PBL).

PBL has been adopted in various processes of education and learning (Yew \& Goh, 2016) because of its enormous benefits. PBL is considered as one of the most effective learning models (Mustaffa \& Ismail, 2015). Various references also inform many positive results of implementing PBL in science learning. PBL is informed of being able to improve concepts mastery, both junior high school (Zakariya, Ibrahim, \& Adisa, 2016), senior high school (Yulianti, 2017), and college students (Zhang et al., 2015). Some studies also report that the application of PBL is also able to empower various students' thinking skills, such as critical (El-Shaer \& Gaber, 2014; Ulger, 2018), creative (Sihaloho, Sahyar, \& Ginting, 2017; Ulger, 2018), metacognitive (Adnan \& Bahri, 2018), and problem-solving thinking skills (Jonassen, 2011).

PBL is not only seen as a learning model but also as an instructional approach that facilitates students to associate the concepts being studied with real situations. In PBL, the situation in real life is positioned as a problem that must be solved by students (Akcay, 2009). Through the problem-solving process, students will try to construct their scientific concepts. Therefore, PBL is considered as a learning model that supports the realization of meaningful learning.

As cooperative learning, PBL directs students to work in groups (Gorghiu, Drăghicescu, Cristea, Petrescu, \& Gorghiu, 2015; Savery, 2006). The group work process will facilitate each group member to discuss their thoughts. They will learn to communicate and learn to work together to achieve the same target. In addition, the demand for heterogeneous groupings as a cooperative principle will help teachers overcome students whose abilities are below average (Arends, 2012; Zamani, 2016). The existence of smart students in each group will encourage other students to participate motivated in completing their assignments.

Unfortunately, even though it has been reported to provide various benefits in the learning process, the application of PBL in Indonesia is still not optimal. Various teachers in several schools still prefer to apply conventional learning (Kurniati \& Surya, 2017; Zulfikar, 2013). One of the causes of this condition is the lack of understanding of science teachers on PBL. Some teachers do not understand the syntax of PBL and some others are not able to implement PBL syntax into the learning plan that they compile. Therefore, the availability of learning resources that can encourage students to learn independently with the principle of PBL is the leading solution to this problem.

One of the recommended learning resources in science learning is the module. A module must be used as teaching material instead of the educator's function. The characteristic of this teaching material has a structured and contains a set of planned learning experiences and is designed to help students' master specific learning goals. The learning module includes a set of activities aimed at facilitating students to achieve learning objectives. Modules are considered as innovative learning resources because they can facilitate students to learn independently. Not surprisingly, various studies report the positive impact of the existence of modules on the learning process (Serrat et al., 2014; Tiantong \& Teemuangsai, 2013). Several development studies have also developed various modules which are expected to be able to improve students' academic achievements (Bahri, Syamsuri, \& Mahanal, 2016; Huda \& Arsana, 2013).

If referring to various previous studies, many studies have examined PBL. Some studies examined the implementation of PBL for thinking skills (Birgili, 2015; Nazir \& Zabit, 2010; Eldy \&Sulaiman, 2014), some others more focus on students' motivation (Argaw, Haile, Ayalew, \& Kuma, 2017; Pelawi \& Sinulingga, 2016). Some other researchers were more trying to integrating PBL with other learning models (Hou, 2014) or technology (Karami, Karami, \& Attaran, 2013), while others prefer modifying this learning model (Burgess, Roberts, Ayton, \& Mellis, 2018; Hudec et al., 2009; Liceaga, Ballard, \& Skura, 2011). However, research that attempts to package PBL in the module form is still rare. The proof is that such modules were still challenging to find in various schools. This kind of research is urgent, given the rare application of PBL in schools due to the inability of teachers to design learning that applies PBL. The existence of such modules will help teachers apply PBL in the learning they hold. Therefore, the purpose of this study was to examine the effectiveness of PBL-based modules in science learning. 


\section{METHOD}

This qualitative descriptive study was conducted at SSHS 2 of Wera, Bima, West Nusa Tenggara. The population in this study were all students of class $\mathrm{XI}$, while students of class $\mathrm{XI}$ natural science were selected as samples. This research was conducted in the even semester of the academic year 2015-2016. Three stages in this research are preliminary data collection, PBL-based module implementation, and final data collection. PBL syntax is integrated into the module as in Table 1.

Table 1. PBL-module based syntax

\begin{tabular}{|c|c|c|}
\hline PBL syntax & Modul & Description \\
\hline Orientation the problem & Discourse & $\begin{array}{l}\text { Giving an overview to the students about the } \\
\text { problems to be learned }\end{array}$ \\
\hline Organize the students & Organizing & $\begin{array}{l}\text { Helping the students in analyzing the problems in } \\
\text { the module }\end{array}$ \\
\hline Group or independent investigation & Investigation & $\begin{array}{l}\text { The students are asked to investigate through } \\
\text { science work }\end{array}$ \\
\hline Developing and presenting the work & Developing and presenting & $\begin{array}{l}\text { Developing their works after doing the laboratory } \\
\text { work }\end{array}$ \\
\hline Analysis and problem solving & Analysing and problem-solving & $\begin{array}{l}\text { write about the obstacles in conducting } \\
\text { investigations }\end{array}$ \\
\hline
\end{tabular}

The variables used as determinants of module effectiveness were students' cognitive learning outcomes. The test instrument was used as a data collection tool in this study. The test instrument consisted of 15 multiple-choice questions. All items have been declared valid, and the test instrument is also declared reliable. All the items also meet the criteria both in the parameters of the difficulty level and the different items. After the data is collected, the data analysis was carried out. Descriptive analysis is used to obtain the average and gain a score of learning outcomes, while the dependent t-test is used to analyze differences before and after the application of the module. Before the t-test is conducted, the Kolmogorov-Smirnov test is used to ensure normality of the data.

\section{RESULTS AND DISCUSSION}

The results of students' pretest and posttest data are used as a basis for analysis to identify whether there are differences in learning outcomes using PBL-based modules. Results of the descriptive analysis, as shown in Table 2, shows an average difference between the pretest and posttest with an N-gain score of 0.74 .

Table 2. Results of descriptive analyze and N-gain calculations

\begin{tabular}{cccc}
\hline Test & Mean & Standard deviation & N-gain \\
\hline Pretest & 39.167 & 10.307 & 0.74 \\
Posttest & 83.917 & 6.071 & \\
\hline
\end{tabular}

The $\mathrm{N}$-gain score in Table 2 indicates a significant difference between the pretest and posttest averages so that an inferential statistical test is necessary. The dependent t-test analyze (Table 3) showed that between pretest $(M=39.167, S D=10.307)$ and posttest $(M=83.917, S D=6.071)$ had a significant difference $[t(23)=$ $25.848, p<0.05]$. Furthermore, the implementation of PBL-based modules can improve learning outcomes of SSHS 2 of Wera students.

Table 3. Dependent t-test result

\begin{tabular}{ccc}
\hline Pair & t value & Sig. \\
\hline Pretest-Posttest & 25.848 & $<0.05$ \\
\hline
\end{tabular}

The results of this study reinforce some previous research which states that the integration of modulebased PBL in learning can improve student learning outcomes (Gorghiu et al., 2015; Miharja, Syamsuri, \& Saptasari, 2015). The implementation carried out steadily and consistently is proven to be able to improve students' critical thinking skills (El-Shaer \& Gaber, 2014; Zabit, 2010). Problems that are used as learning resources become triggers that respond to students' thinking skills (Jonassen, 2011; Sada, Mohd, Adnan, \& Yusri, 2016). Thus, students become conditioned to be able to literate various completion hypotheses (Jonassen, 2011; Klucevsek \& Brungard, 2016). The existence of collaborative efforts in a learning group 
enriches the hypothesis so that students can see the problem from a different perspective (Iversen, Pedersen, Krogh, \& Jensen, 2015; McCrum, 2017; Serevina, Sunaryo, Raihanati, Astra, \& Sari, 2018).

On the other hand, the characteristics of the learning modules that emphasize independent learning activities according to some researchers provide maximum learning space for students (Leow \& Neo, 2014; Maryani, Martaningsih, \& Bhakti, 2017; Serrat et al., 2014). This statement refers to research Rufii (2015); Waluyo, Prayitno, and Sugiyarto (2017), which states that students who learn to use modules can think constructively. The completeness of features in a module based on PBL, according to some researchers, provides a logical picture to students in solving problems or understanding a phenomenon, including making observations (Belecina \& Ocampo, 2018), analyzing (Setiyadi, Ismail, \& Gani, 2017), making hypotheses (Ergul et al., 2011; Jiun \& Nurzatulshima, 2014), conducting investigations (Argaw et al., 2017; Zabit, 2010), and making conclusions (Ravitz, 2009).

Besides, the characteristics of science learning that study a problem or phenomenon, by some researchers, are considered appropriate when done with the PBL model (Lewinsohn et al., 2014; Serevina et al., 2018; Siswati \& Corebima, 2017). However, the teacher needs to analyze the accuracy of the media and the learning strategies that are appropriate for discussing a particular material (Ismail, Harun, Zakaria, \& Salleh, 2017; McCrum, 2017). These analyze is essential because the material presented with the right media and strategies can maximize student learning potential (Gay, Mills, \& Airasian, 2012; Miri, David, \& Uri, 2007). In this case, the selection of PBL-based modules used in the learning process is considered to meet these elements, indicated by an increase in value from pretest to posttest.

The results of this study certainly need to be continued with further research, such as the analysis of students' critical thinking skills. However, an increase in learning outcomes is a positive indicator of the implementation of PBL-based modules in learning. Furthermore, this study recommends the use of PBL-based modules in learning, especially science learning.

\section{CONCLUSION}

Implementation of learning by using PBL-based modules can optimize student learning abilities so that it has an impact on improving learning outcomes, seen from differences in achievements before and after using the module.

\section{ACKNOWLEDGMENT}

This research was supported by the participation of various parties. Greatly appreciate for the support of Director of Postgraduate School, Universitas Negeri Sebelas Maret, School Principal and teacher of SSHS 1 of Wera, West Nusa Tenggara.

\section{REFERENCES}

Adnan, A., \& Bahri, A. (2018). Beyond effective teaching: Enhancing students' metacognitive skill through guided inquiry. In Journal of Physics: Conference Series (Vol. 954, p. 12022). doi: https://doi.org/10.108 8/1742-6596/954/1/012022

Ajaja, O. P. (2013). Which strategy best suits biology teaching? Lecturing, concept mapping, cooperative learning or learning cycle?. Electronic Journal of Science Education, 17(1), 1-37. Retrieved from http:/l ejse.southwestern.edu/article/viewFile/11522/8115

Ajaja, O. P., \& Eravwoke, O. U. (2010). Effects of cooperative learning strategy on junior secondary school students achievement in integrated science. Electronic Journal of Science Education, 14(1), 1-18. Retrieved from http://ejse.southwestern.edu/article/view/7323

Akcay, B. (2009). Problem-based learning in science education. Journal of Turkish Science Education, 6(1), 26-36. Retrieved from https://www.pegem.net/dosyalar/dokuman/48116-20090429114931-04problembased-learning-in-science-education.pdf

Alfares, N. (2017). Benefits and difficulties of learning in group work in EFL classes in Saudi Arabia. English Language Teaching, 10(7), 247. doi: https://doi.org/10.5539/elt.v10n7p247

Arends, R. I. (2012). Learning to teach (Ninth). New York, USA: McGraw-Hill. Retrieved from https://hasan ahummi.files.wordpress.com/2017/04/connect-learn-succeed-richard-arends-learning-to-teach-mcgrawhill-2012.pdf 
Argaw, A. S., Haile, B. B., Ayalew, B. T., \& Kuma, S. G. (2017). The effect of problem based learning (PBL) instruction on students' motivation and problem solving skills of physics. Eurasia Journal of Mathematics, Science and Technology Education, 13(3), 857-871. doi: https://doi.org/10.12973/eurasia .2017.00647a

Asrizal, Amran, A., Ananda, A., Festiyed. (2017). Need analysis to develop adaptive contextual learning model. In Proceeding of the 2nd International Conference on Teacher Education (Vol. 1, pp. 78-83). doi: https://doi.org/10.17605/osf.io/fhkcp

Bahri, S., Syamsuri, I., \& Mahanal, S. (2016). Pengembangan modul keanekaragaman hayati dan virus berbasis model inkuiri terbimbing untuk siswa kelas X MAN 1 Malang. Jurnal Pendidikan: Teori, Penelitian, dan Pengembangan, 1(2), 127-136. doi: https://doi.org/10.17977/jp.v1i2.6113

Barke, H.-D., Hazari, A., \& Yitbarek, S. (2009). Misconceptions in chemistry. Berlin: Springer-Verlag. https://doi.org/10.1007/978-3-540-70989-3

Belecina, R. R., \& Ocampo, J. M. (2018). Effecting change on students' critical thinking in problem solving. EDUCARE: International Journal for Educational Studies International Journal for Educational Studies. 10(102), 109-118. Retrieved from http://journals.mindamas.com/index.php/educare/article/view/949

Birgili, B. (2015). Creative and critical thinking skills in problem-based learning environments. Journal of Gifted Education and Creativity, 2(2), 71-80. doi: https://doi.org/10.18200/JGEDC.2015214253

Buah, E., \& Akuffo, A. F. (2017). The Science Topics Perceived Difficult by Junior High School Students at Techiman North District: Effects on the teaching and learning of Science. Imperial Journal of Interdisciplinary Research, 3(1), 503-509. Retrieved from https://www.onlinejournal.in/IJIRV3/1/089.pdf

Burgess, A., Roberts, C., Ayton, T., \& Mellis, C. (2018). Implementation of modified team-based learning within a problem based learning medical curriculum: A focus group study. BMC Medical Education, 18(1), 1-7. doi: https://doi.org/10.1186/s12909-018-1172-8

Dogra, B. (2010). Constructivist classroom activities for biology learning. Education India Journal, 36(1), 1-15. doi: https://doi.org/10.1016/j.porgcoat.2009.04.010

Eldy, E. F., \& Sulaiman, F. (2014). Integrated PBL approach: Findings towards physics students' critical thinking. International Journal for Innovation Education and Research, 2(2), 75-81. Retrieved from http ://www.ijeeee.org/Papers/257-N10032.pdf

El-Shaer, A., \& Gaber, H. (2014). Impact of problem-based learning on student critical thinking dispositions, knowledge acquisition and retention. Journal of Education and Practice, 5(14), 74-85. doi: https://doi .org/10.1021/ol1022257

Ergul, R., Simsekli, Y., Calis, S., Ozdilek, Z., Gocmencelebi, S., \& Sanli, M. (2011). The effects of inquirybased science teaching on elementary school students 'science process skills and science attitudes. Bulgarian Journal of Science and Education Policy (BJSEP), 5(1), 48-68. Retrieved from http://bjsep. org/getfile.php?id=88

Etobro, A. B., \& Fabinu, O. E. (2017). Students' perceptions of difficult concepts in Biology in senior secondary schools in Lagos State. Global Journal of Educational Research, 16, 139-147. doi: https:// doi.org/10.4314/gjedr.v16i2.8

Fleischner, T. L., Espinoza, R. E., Gerrish, G. A., Greene, H. W., Kimmerer, R. W., Lacey, E. A., ... Zander, L. (2017). Teaching biology in the field: Importance, challenges, and solutions. BioScience, 67(6), 558567. doi: https://doi.org/10.1093/biosci/bix036

Gay, L. R., Mills, G. L., \& Airasian, P. (2012). Educational research: competencies for analysis and application. Boston: Pearson. Retrieved from http://englishlangkan.com/produk/E Book Educational Research L R Gay Pearson 2012.pdf

Gorghiu, G., Drăghicescu, L. M., Cristea, S., Petrescu, A.-M., \& Gorghiu, L. M. (2015). Problem-based Learning - An efficient learning strategy in the science lessons context. In Procedia - Social and Behavioral Sciences (Vol. 191, pp. 1865-1870). Elsevier. doi: https://doi.org/10.1016/j.sbspro.2015.04. 570

Hou, S. I. (2014). Integrating problem-based learning with community-engaged learning in teaching program development and implementation. Universal Journal of Educational Research, 2(1), 1-9. doi: https://doi. org/10.13189/ujer.2014.020101

Huda, M. S., Arsana, I. M. (2013). Pengembangan modul pembelajaran thermal radiation untuk menunjang perkuliahan perpindahan panas mahasiswa D3 Teknik Mesin FT UNESA. Jurnal Pendidikan Teknik Mesin, 2(1), 15-23. Retrieved from https://jurnalmahasiswa.unesa.ac.id/index.php/jurnal-pendidikan-tek nik-mesin/article/view/3349 
Hudec, R., Tisonova, J., Bozekova, L., Wawruch, M., Kriska, M., \& Kristova, V. (2009). Modified problembased learning in pharmacology. Bratislava Medical Journal, 110(11), 732-735. Retrieved from https:// www.ncbi.nlm.nih.gov/pubmed/20120447

Ismail, N. S., Harun, J., Zakaria, M. A. Z. M., \& Salleh, S. M. (2017). The effect of mobile problem-based science dictionary application dicscience PBL towards students' mastery of scientific terms and critical thinking. In 2017 International Conference on Learning and Teaching in Computing and Engineering (LaTICE) (pp. 69-75). IEEE. doi: https://doi.org/10.1109/LaTiCE.2017.19

Iversen, A., Pedersen, A. S., Krogh, L., \& Jensen, A. A. (2015). Learning, leading, and letting go of control: Learner-led approaches in education. SAGE Open, 5(4), 1-11. doi: https://doi.org/10.1177/215824401 5608423

Jiun, L. T., \& Nurzatulshima, K. (2014). Inquiry in learning. International Journal of Technical Research and Applications, 10, 61-65. doi: https://doi.org/10.1007/978-1-4419-1428-6_4377

Jonassen, D. (2011). Supporting problem solving in PBL. Interdisciplinary Journal of Problem-Based Learning, 5(2), 95-119. doi: https://doi.org/10.7771/1541-5015.1256

Kadbey, H., Dickson, M., \& McMinn, M. (2015). Primary teachers' perceived challenges in teaching science in Abu Dhabi public schools. In Procedia - Social and Behavioral Sciences (Vol. 186, pp. 749-757). Elsevier B.V. doi: https://doi.org/10.1016/j.sbspro.2015.04.055

Karami, M., Karami, Z., \& Attaran, M. (2013). Integrating problem-based learning with ICT for developing trainee teachers' content knowledge and teaching skill. Journal of Education and Development Using Information and Communication Technology (IJEDICT), 9(1), 36-49. Retrieved from https://eric.ed.gov/ ?id=EJ1071352

Karpudewan, M., Zain, A. N. M., \& Chandrasegaran, A. L. (2017). Overcoming students' misconceptions in science. Singapore: Springer Nature Singapore Pte Ltd. doi: https://doi.org/10.1007/978-981-10-3437-4

Klucevsek, K. M., \& Brungard, A. B. (2016). Information literacy in science writing: how students find, identify, and use scientific literature. International Journal of Science Education, 38(17), 2573-2595. doi: https://doi.org/10.1080/09500693.2016.1253120

Kola, A. J. (2013). Importance of science education to national development and problems militating against its development. American Journal of Educational Research, 1(7), 225-229. doi: https://doi.org/10. 12691/education-1-7-2

Kurniati, I., \& Surya, E. (2017). Student's perception of their teacher teaching style's. International Journal of Sciences: Basic and Applied Research (IJSBAR), 33(2), 91-98. Retrieved from https://www. researchgate.net/publication/318552302_Student's_Perception_of_their_Teacher_Teaching_Style's

Lai, E. (2011). Motivation: A literature review. Alwasy Learning. Retrieved from https://images.pearson assessments.com/images/tmrs/Motivation_Review_final.pdf

Leow, F.-T., \& Neo, M. (2014). Interactive multimedia learning: innovating classroom education in a Malaysian University. TOJET: The Turkish Online Journal of Educational Technology, 13(2), 99-110. Retrieved from http://www.tojet.net/articles/v13i2/13211.pdf

Lewinsohn, T. M., Attayde, J. L., Fonseca, C. R., Ganade, G., Jorge, L. R., Kollmann, J., ... Wolfgang W Weisse. (2014). Ecological literacy and beyond : Problem-based learning for future professionals. Royal Swedish Academy of Sciences, Juni, 1-9. doi: https://doi.org/10.1007/s13280-014-0539-2

Liceaga, A. M., Ballard, T. S., \& Skura, B. J. (2011). Incorporating a modified problem-based learning Exercise in a traditional lecture and lab-based dairy products course. Journal of Food Science Education, 10(2), 19-22. doi: https://doi.org/10.1111/j.1541-4329.2011.00117.x

Maryani, I., Martaningsih, S. T., \& Bhakti, C. P. (2017). Module based on pedagogical content knowledge to increase the engagement and skills of the future teachers in designing a lesson plan. Journal of Education and Learning (EduLearn), 11(1), 91-102. doi: https://doi.org/10.11591/edulearn.v11i1.5758

McCrum, D. P. (2017). Evaluation of creative problem-solving abilities in undergraduate structural engineers through interdisciplinary problem-based learning. European Journal of Engineering Education, 42(6), 684-700. doi: https://doi.org/10.1080/03043797.2016.1216089

Miharja, F. J., Syamsuri, I., \& Saptasari, M. (2015). Pengembangan modul anatomi fisiologi manusia dengan model pembelajaran berbasis masalah untuk meningkatkan kompetensi mahasiswa program studi pendidikan biologi. In Prosiding Seminar Nasional Pendidikan Biologi (pp. 220-227). Malang. Retrieved from http://research-report.umm.ac.id/index.php/research-report/article/viewFile/459/683

Miri, B., David, B., \& Uri, Z. (2007). Purposely teaching for the promotion of higher-order thinking skills: A case of critical thinking. Research in Science Education, 37, 353-369. doi: https://doi.org/10.1007/s11165- 
006-9029-2

Mustaffa, N., \& Ismail, Z. (2015). Problem-Based Learning (PBL) in schools: A meta-analysis. In 12th International Conference of The Mathematics Education into the 21st Century Project The Future of Mathematics Education in a Connected World. Herceg Novi. Retrieved from https://directorymathsed .net/montenegro/Mustaffa.pdf

Nazir, M., \& Zabit, M. (2010). Problem-based learning on students' critical thinking skills in teaching business education in Malaysia: A literature review. American Journal of Business Education, 3(6), 19-32. Retrieved from https://eric.ed.gov/?id=EJ1058610

Omorogbe, E., \& Ewansiha, J. (2013). The challenge of effective science teaching in Nigerian secondary schools. Academic Journal of Interdisciplinary Studies, 2(7), 181-188. doi: https://doi.org/10.5901/ajis. 2013.v2n7p181

Pelawi, H. S., \& Sinulingga, K. (2016). Pengaruh model problem based learning dan motivasi belajar terhadap hasil belajar siswa di kelas X SMA Sinar Husni. Jurnal Pendidikan Fisika, 5(1), 32-37. doi: https://doi. org/10.22611/jpf.v5i1.3704

Putrayasa, I. B. (2018). Teaching and learning of Indonesian by constructivism model with inquiry approach. KnE Social Sciences, 3(9), 764-772. doi: https://doi.org/10.18502/kss.v3i9.2740

Rahayu, S. (2017). Promoting the 21st century scientific literacy skills through innovative chemistry instruction. In AIP Conference Proceedings (Vol. 20025, p. 20025). AIP Publishing. doi: https://doi.org/ $10.1063 / 1.5016018$

Ravitz, J. (2009). Introduction: Summarizing findings and looking ahead to a new generation of PBL research. Interdisciplinary Journal of Problem-Based Learning, 3(1), 4-11. doi: https://doi.org/10.7771/1541-5015. 1088

Rufii, R. (2015). Developing module on constructivist learning strategies to promote students' independence and performance. International Journal of Education, 7(1), 18-28. doi: https://doi.org/10.5296/ije.v7i1. 6675

Sada, A. M., Mohd, Z. A., Adnan, A., \& Yusri, K. (2016). Prospects of problem-based learning in building critical thinking skills among technical college students in Nigeria. Mediterranean Journal of Social Sciences, 7(3), 356-365. doi: https://doi.org/10.5901/mjss.2016.v7n3p356

Savery, J. R. (2006). Overview of problem-based learning: definitions and distinctions. Interdisciplinary Journal of Problem-Based Learning, 1(1), 13. doi: https://doi.org/10.7771/1541-5015.1002

Serevina, V., Sunaryo, S., Raihanati, R., Astra, I. M., \& Sari, I. J. (2018). Development of e-module based on Problem Based Learning (PBL) on heat and temperature to improve student's science process skill. The Turkish Online Journal of Educational Technology, 17(3), 26-37. Retrieved from https://eric.ed.gov /? id=EJ1184205

Serrat, M. A., Dom, A. M., Buchanan, J. T., Williams, A. R., Efaw, M. L., \& Richardson, L. L. (2014). Independent learning modules enhance student performance and understanding of anatomy. Anatomical Sciences Education, 7(5), 406-416. doi: https://doi.org/10.1002/ase.1438

Setiyadi, M. W., Ismail, I., \& Gani, H. A. (2017). Pengembangan modul pembelajaran biologi berbasis pendekatan saintifik untuk meningkatkan hasil belajar siswa. Journal of Educational Science and Technology, 3(2), 102-112. doi: https://doi.org/10.26858/est.v3i2.3468

Shaaruddin, J., \& Mohamad, M. (2017). Identifying the effectiveness of active learning strategies and benefits in curriculum and pedagogy course for undergraduate TESL students. Creative Education, 8(14), 23122324. doi: https://doi.org/10.4236/ce.2017.814158

Shirazi, S. (2017). Student experience of school science. International Journal of Science Education, 39(14), 1891-1912. doi: https://doi.org/10.1080/09500693.2017.1356943

Sihaloho, R. R., Sahyar, S., \& Ginting, E. M. (2017). The effect of Problem Based Learning (PBL) model toward student's creative thinking and problem solving ability in senior high school. IOSR Journal of Research \& Method in Education (IOSRJRME), 7(4), 11-18. doi: https://doi.org/10.9790/7388-07040 11118

Siswati, B. H., \& Corebima, A. D. (2017). Study on the correlation between metacognitive skills and concept gaining of biology at several learning models. In Asia-Pacific Forum on Science Learning and Teaching (Vol. 18, pp. 1-14). Retrieved from https://eric.ed.gov/?id=EJ1160094

Slavin, R. E. (2014). Cooperative learning and academic achievement: Why does groupwork work? Anales de Psicología, 30(3), 785-791. doi: https://doi.org/10.6018/analesps.30.3.201201

Suryawati, E., \& Osman, K. (2018). Contextual learning: Innovative approach towards the development of 
students' scientific attitude and natural science performance. Eurasia Journal of Mathematics, Science and Technology Education, 14(1), 61-76. doi: https://doi.org/10.12973/ejmste/79329

Tiantong, M., \& Teemuangsai, S. (2013). The four scaffolding modules for collaborative problem-based learning through the computer network on moodle Ims for the computer programming course. International Education Studies, 6(5), 47-55. doi: https://doi.org/10.5539/ies.v6n5p47

Tompo, B., Ahmad, A., \& Muris, M. (2016). The development of discovery-inquiry learning model to reduce the science misconceptions of junior high school students. International Journal of Environmental and Science Education, 11(12), 5676-5686. Retrieved from http://www.ijese.net/makale_indir/732

Ulger, K. (2018). The effect of problem-based learning on the creative thinking and critical thinking disposition of students in visual arts education. Interdisciplinary Journal of Problem-Based Learning, 12(1). doi: https://doi.org/10.7771/1541-5015.1649

Waluyo, S., Prayitno, B. A., \& Sugiyarto, S. (2017). Pengembangan modul berbasis guided discovery pada materi jamur untuk meningkatkan kemampuan berpikir analitis. Jurnal Inkuiri, 6(1), 61-74. doi: https ://doi.org/10.20961/inkuiri.v6i1.17266

Yew, E. H. J., \& Goh, K. (2016). Problem-based learning: An overview of its process and impact on learning. Health Professions Education, 2(2), 75-79. doi: https://doi.org/10.1016/j.hpe.2016.01.004

Yulianti, D. (2017). Problem-based learning model used to scientific approach based worksheet for physics to develop senior high school students characters. In Journal of Physics: Conference Series (Vol. 824, p. 12009). doi: https://doi.org/10.1088/1742-6596/824/1/012009

Zabit, M. N. M. (2010). Problem-based learning on students critical thinking skills in teaching business education in Malaysia: A literature review. American Journal of Business Education (AJBE), 3(6), 1932. doi: https://doi.org/10.19030/ajbe.v3i6.436

Zakariya, Y. F., Ibrahim, M. O., \& Adisa, L. O. (2016). Impacts of problem-based Learning on performance and retention in mathematics among junior secondary school students in Sabon-Gari Area of Kaduna State. International Journal for Innovative Research in Multidisciplinary Field, 2(9), 42-47. Retrieved from https://www.researchgate.net/publication/308718640_Impacts_of_Problem-Based_Learning_on_P erformance_and_Retention_in_Mathematics_among_Junior_Secondary_School_Students_in_Sabon-G ari_Area_of_Kaduna_State

Zamani, M. (2016). Cooperative learning: Homogeneous and heterogeneous grouping of Iranian EFL learners in a writing context. Cogent Education, 3(1), 1-11. doi: https://doi.org/10.1080/2331186X.2016.1149959

Zhang, Y., Zhou, L., Liu, X., Liu, L., Wu, Y., Zhao, Z., ... Yi, D. (2015). The Effectiveness of the Problembased learning teaching model for use in Introductory Chinese Undergraduate Medical Courses: A systematic review and meta-analysis. PLOS ONE, 10(3). doi: https://doi.org/10.1371/journal.pone.0120 884

Zulfikar, T. (2013). Looking from within: Prospects and challenges for progressive education in Indonesia. International Journal of Progressive Education, 9(3), 124-136. Retrieved from https://dergipark.org.tr/ download/article-file/258584 